\title{
Social learning for resilience in social--ecological systems
}

Citation for published version (APA):

de Kraker, J. (2017). Social learning for resilience in social--ecological systems. Current Opinion in Environmental Sustainability, 28, 100-107. https://doi.org/10.1016/j.cosust.2017.09.002

Document status and date:

Published: 01/10/2017

DOI:

10.1016/j.cosust.2017.09.002

Document Version:

Publisher's PDF, also known as Version of record

Document license:

Taverne

Please check the document version of this publication:

- A submitted manuscript is the version of the article upon submission and before peer-review. There can be important differences between the submitted version and the official published version of record.

People interested in the research are advised to contact the author for the final version of the publication, or visit the DOI to the publisher's website.

- The final author version and the galley proof are versions of the publication after peer review.

- The final published version features the final layout of the paper including the volume, issue and page numbers.

Link to publication

\footnotetext{
General rights rights.

- You may freely distribute the URL identifying the publication in the public portal. please follow below link for the End User Agreement:

www.umlib.nl/taverne-license

Take down policy

If you believe that this document breaches copyright please contact us at:

repository@maastrichtuniversity.nl

providing details and we will investigate your claim.
}

Copyright and moral rights for the publications made accessible in the public portal are retained by the authors and/or other copyright owners and it is a condition of accessing publications that users recognise and abide by the legal requirements associated with these

- Users may download and print one copy of any publication from the public portal for the purpose of private study or research.

- You may not further distribute the material or use it for any profit-making activity or commercial gain

If the publication is distributed under the terms of Article $25 \mathrm{fa}$ of the Dutch Copyright Act, indicated by the "Taverne" license above, 


\section{Social learning for resilience in social-ecological systems Joop de $\mathrm{Kraker}^{1,2}$}

\begin{abstract}
Fostering of social learning is generally considered an important governance instrument to build resilience in social-ecological systems. Empirical studies addressing the contribution of social learning to resilience are scarce however, and do not provide direct evidence but infer this contribution from the impacts of social learning on system governance and management. These impacts are found more frequently at the local level than at higher, regional or national levels, probably depending on the overlap between participants in social learning and actors in governance and management. Recent studies have shown that at higher levels a connection between social learning and policy can be achieved through bridging actors or organizations, and vertical linkages between governance levels. Conceptually and methodologically the study of social learning and its relation with resilience has advanced sufficiently to enable more rigorous and detailed empirical research. This should focus on how attempts to foster social learning within social-ecological governance systems can be made more effective and efficient, for example, through the use of new technologies to support the learning process or through the creation of permanent, informal multistakeholder learning spaces within formal policy structures.
\end{abstract}

\footnotetext{
Addresses

${ }^{1}$ Faculty of Management, Science \& Technology, Open Universiteit, P.O. Box 2960, 6401 DL Heerlen, The Netherlands

${ }^{2}$ International Centre for Integrated Assessment and Sustainable Development (ICIS), Maastricht University, P.O. Box 616, 6200 MD Maastricht, The Netherlands
}

Corresponding author: de Kraker, Joop (joop.dekraker@ou.nl)

Current Opinion in Environmental Sustainability 2017, 28:100-107

This review comes from a themed issue on Sustainability governance Edited by Carolien Kroeze, Marjolein Caniels, Dave Huitema and Harald Vranken

For a complete overview see the Issue and the Editorial

Available online 29th September 2017

Received: 8 May 2017; Accepted: 5 September 2017

http://dx.doi.org/10.1016/j.cosust.2017.09.002

1877-3435/@ 2017 Elsevier B.V. All rights reserved.

\section{Introduction}

Attention for the role of learning in building resilience can be traced back to the early stages of resilience thinking $\left[1,2^{\circ}\right]$. The relationship between learning and resilience is conceptually simple. Social-ecological systems are characterized by a close, dynamic interaction between social groups and their natural environment [3]. Learning about undesirable environmental changes is a pre-condition for responding to these changes, and the ability of social groups to respond to change generates resilience [4,5], which is the capacity of a system to experience shocks while retaining essentially the same identity $[6,7]$. More recently, resilience has also come to include transformability, the capacity to create a fundamentally new system when the existing system has become unsustainable [8]. The central role of learning is reflected in Folke's [9] definition of resilience of socialecological systems which includes the capacity for learning and adaptation.

Learning is a change in knowledge, skills or attitudes, that may result in changes in behavior, or even institutions $\left[1,10^{\circ}\right]$. Social learning is learning by social groups, resulting in changes at group level, through social interaction [11]. History provides many examples from traditional societies adapting to environmental change, presumably through social learning [12]. In these examples, social learning emerged from a form of social self-organization [4]. Yet, their success has inspired scholars to consider organized settings to foster social learning as an important adaptive governance instrument for building resilience in contemporary social-ecological systems $[8,13,14]$. Adaptive governance is a multi-actor, multilevel decision-making approach with the aim to adaptively negotiate and coordinate management of socialecological systems, with demonstrated positive effects on natural capital $\left[15^{\circ}\right]$.

A recent review on the role of learning in building resilience of ecosystem services concluded however, that there is a need for greater conceptual clarity on what social learning is and how it contributes to resilience $\left[2^{\circ}\right]$. Furthermore, the authors considered the evidence about the importance of social learning and the mechanisms by which it enhances the resilience of social-ecological systems to be unclear. The aim of this paper is first to present an integrated conceptualization of how social learning may contribute to resilience of social-ecological systems, and, second, to assess the empirical evidence for the contributions of social learning to resilience. The focus is on social learning for resilience, that is, on the intentional, instrumental use of social learning processes as a mechanism to build resilience in social-ecological systems. Throughout the paper a distinction is made between the settings 


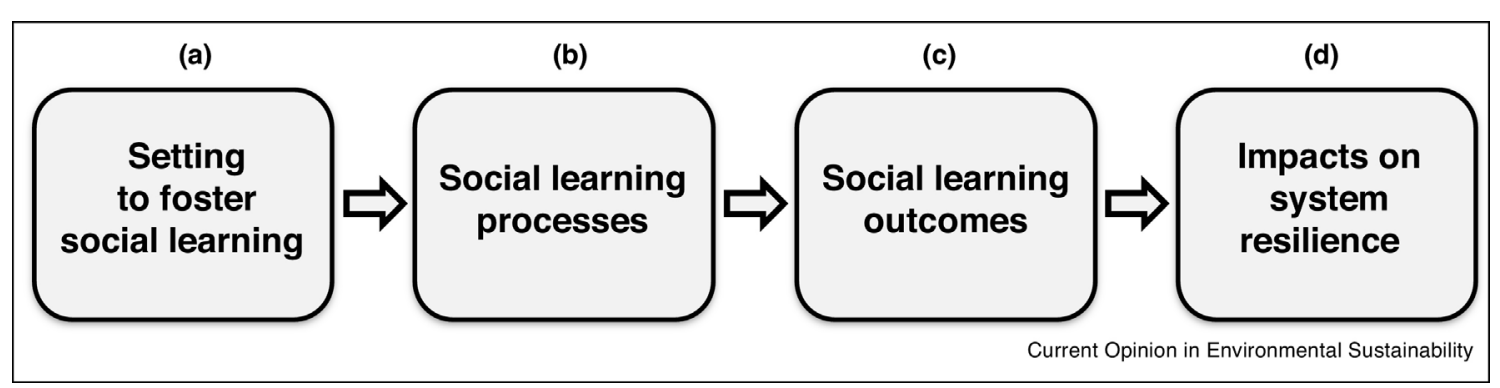

From interventions fostering social learning to impacts on system resilience: (a) a setting is organized for communicative interactions between a heterogeneous group of actors, with the intention to foster social learning among these actors; (b) this may result in social learning processes taking place, interactions that bring about cognitive or relational changes at group level; (c) possible outcomes of social learning include a common understanding of a problem or more trust among the actors; (d) finally, these outcomes may translate in enhanced system resilience through real-world changes in management and governance of social-ecological systems.

to foster social learning, social learning processes, social learning outcomes, and social learning impacts (Figure 1) $\left[10^{\bullet}, 11\right]$. Wider outcomes and impacts beyond the group involved in the social learning processes are considered here as (in part) contributions of social learning, but the activities by which they are achieved (e.g. mass media dissemination, lobbying) are not considered to be part of the social learning process.

\section{Conceptualizing social learning for resilience}

Although learning in general is since long an important concept in resilience thinking, there are only a few publications from before 2000 that make an explicit connection between resilience and social learning. The earliest sources that mention both concepts in the context of social-ecological systems, portray social learning as an emergent, self-organized process of corrective societal change in response to unsustainable resource management [16,17]. Not until 1999, it was suggested that social learning could be intentionally fostered as an adaptive mechanism to build resilience [18]. Since then, fostering social learning has received increasing attention as a governance instrument, in particular in participatory natural resource management (e. g. [19-21]), adaptive management of ecosystems (e.g. $[5,22,23])$, and adaptation to climate change and natural hazards (e.g. [24,25]).

As the concept of social learning became more popular, the confusion about its meaning also increased $\left[10^{\circ}\right]$. A major step in reaching more conceptual clarity has been the proposal by Reed et al. [11], to define social learning as a change in understanding, that goes beyond the individual and occurs through social interactions. Ideally, this definition functions as a baseline and depending on the study the definition of social learning may include additional criteria, for example, learning must be convergent towards a common understanding [26,27], or encompass a wider set of outcomes, for example, changes in relations among the group members [28]. As Cundill and Rodela [28] observed, a broad distinction in this respect can be made between the literature on adaptive (co-)management, where social learning is mostly about cognitive changes in understanding and coping with uncertainty, and the literature on participatory natural resource management, where it often also includes relational changes, such as more trust and better working relations among the participants to enable collective action. The major type of social interaction through which all these changes may occur is by joint, discursive reflection on information about the system to be managed $\left[29,30^{\circ}\right]$. The sources of information may range from collective experiences, experiments, monitoring data, computer simulations, and external experts, to the knowledge, views and experiences of other members of the social group [1,2,29]. Here again a distinction can be observed between the literature on adaptive (co-)management, with an emphasis on experimentation, and the literature on participatory natural resource management, emphasizing deliberation and dialogue [28].

In resilience thinking, learning is given a central role in the adaptive cycle (Figure 2) $\left[31,32^{\circ}\right]$. The adaptive cycle is a conceptual model of the dynamics and resilience of ecological, social and social-ecological systems. In different stages of the cycle, learning plays different roles: in the 'front loop', learning is associated with incremental, optimization-type innovation to enable further growth, whereas in the 'back loop', it is associated with more radical types of innovation in response to crises in the system. A third, 'transformational' type of learning occurs when learning outcomes, innovations developed during the back loop at lower levels of the social-ecological system, are taken up in the front loop at a higher level. These three forms of learning match a common typology in learning which distinguishes single-loop learning (incremental change, improvement of the effectiveness of actions to meet predefined goals), double-loop learning (more fundamental 
Figure 2

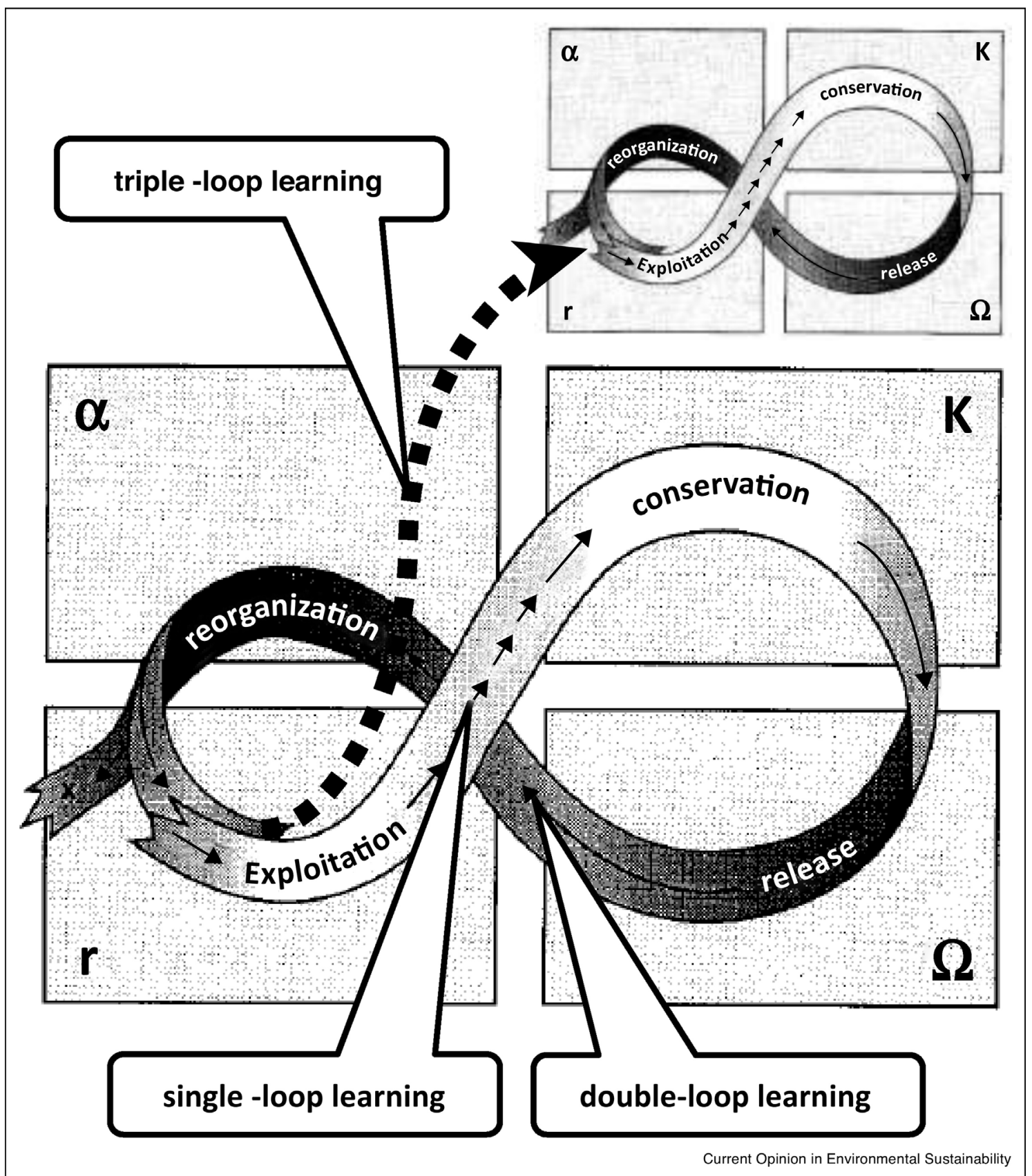

The adaptive cycle with the four principal phases that a system can cycle through: exploitation $(r)$, conservation $(K)$, release $(\Omega)$, and reorganization $(\alpha)$. The phases are connected by two 'loops': the front loop (from $r$ to $K$ ) is characterized by stable conditions and growth, initially fast and slowly reaching a plateau; the back loop (from $\Omega$ to $\alpha$ ) is characterized by unpredictability and initial disintegration after a crisis, followed by renewal, sometimes also at higher levels of the system. The back loop thus provides for the resilience of the system. In different phases of the cycle, different types of learning play a role. Double or triple-loop learning during the back loop is associated with social learning.

Source: Adapted from Panarchy by Lance Gunderson and C.S. Holling. Copyright $\odot 2002$ Island Press. Reproduced by permission of Island Press, Washington, DC [31,32].

change, rethinking the underlying assumptions and redefining goals) and triple-loop learning (paradigm change, questioning the norms and values underpinning the current governance regime) $\left[14,29,33,34^{\bullet \bullet}\right]$. In the context of resilience, social learning is usually connected to double or triple-loop learning during the back loop: as a way to recognize the challenges (or even crises) the system faces, understand the need for more fundamental change, and 
explore novel perspectives and solutions [35]. The strength of social learning in this respect is twofold. The diversity of knowledge, expertise and viewpoints in the group can help to make a balanced assessment of the collective problem and develop novel and socially robust solutions, and the collective learning can generate common ground and trust for joint action $[36,37]$.

In particular in participatory natural resource management, fostering of social learning was initially seen as the ideal, non-coercive approach to address collective problems in social-ecological systems that require a collective or coordinated response [38]. However, years of research have made clear that the niche for fostering of social learning as an effective governance instrument is rather limited, that is, there are not many situations where there is a good chance of achieving the desired outcomes. Whether organized, joint reflection on information about the system to be managed by a heterogeneous group of actors does result in desired social learning outcomes such as consensus about the problem and socially robust solutions, depends on a broad range of case-related and process-related factors $\left[4,10^{\bullet}, 29,39-43\right]$. Important case-related conditions promoting social learning are first of all a balance of power and strong interdependence between the stakeholders in solving the problem. Other case-related factors are overlapping values and interests, trust, limited risk, a supportive institutional context, and a sense of urgency and awareness of the need to change among the stakeholders. Major process-related factors include a balanced, diverse stakeholder selection, effective leadership or facilitation, space for reflection, a safe and informal environment, and transparency. These process requirements, combined with the frequently mentioned need for long-term engagement and repeated meetings $\left[1,2,4,10^{\bullet}, 44\right]$, make fostering of social learning as an intentional intervention a resourceintensive investment with a modest chance of success in terms of desired learning outcomes.

\section{Contributions of social learning to resilience}

Although there is by now a fair understanding of the conditions under which interventions fostering social learning may generate the desired learning outcomes, much less is known about their contributions to the resilience of social-ecological systems [ $\left.2^{\circ}\right]$. To gain more insight, a review was conducted of empirical studies published over the past 10 years (2007-2016), using 'social learning' and 'resilience' as topic search terms in the Web of Science Core collection. ${ }^{1}$ After excluding all publications that were not empirical $(\mathrm{N}=44)$, not about intentional interventions $(\mathrm{N}=32)$, not about social-ecological systems $(\mathrm{N}=24)$, or where the search terms had a very different meaning than in this paper $(\mathrm{N}=15)$, the initial set of 125 publications was reduced to only

\footnotetext{
${ }^{1}$ This yields all publications with both the terms 'social learning' and 'resilience' in the title, abstract or keywords.
}

10 empirical studies. $^{2}$ These studies concern successful initiatives to generate social learning among multiple actors, covering a wide range of social-ecological systems, scales and issues. Following the conceptual framework in Figure 1, the articles were analyzed with respect to the object of social learning, the participants, the learning outcomes, and the impacts on governance and management of the social-ecological system (Table 1). Also, all statements about the contribution of social learning to resilience, or the lack thereof, were considered.

Social learning outcomes were identified in all cases, cognitive (e.g. shared understanding of problem, new responses) and/or relational (e.g. trust, networks). There were no apparent differences in learning outcomes between the local $[43,47,51,52,54]$ and regional cases $[48,49,50,55]$. For the national cases $\left[53^{\bullet \bullet}\right]$, the learning outcomes were not specified. In terms of impacts, changes in governance and management (e.g. better communication, less conflicts, new practices adopted) were reported in most local cases $[43,47,51,52]$ and half of the regional cases $[48,49]$. For the national cases $\left[53^{\circ}\right]$, the researchers concluded that the institutionalization of lessons from social learning in governance had failed. Remarkably, in none of the studies attempts were made to operationalize and measure resilience, and conclusions about the contribution of social learning to resilience were consequently based post hoc on theoretical considerations. The general line of reasoning was that in case social learning helped to respond effectively to undesirable changes or states in the social-ecological system, it contributed to the adaptive capacity of the system and therefore ultimately to its resilience.

Translation of social learning outcomes into adaptive changes in governance and management of social-ecological systems, appears more difficult at higher levels and larger scales. As the cognitive and relational learning outcomes seem to be rather 'sticky', that is, not easily transferred from the group and level where they were acquired [56], the major factor is probably the distance between the informal learning process and the formal policy process $\left[34^{\circ}\right]$. At the local level, transfer and institutionalization of social learning outcomes is facilitated by a large overlap between the participants in the social learning process and the actors responsible for governance and management. In the two regional cases with impacts, there was also a close connection between

\footnotetext{
${ }^{2}$ In the literature, alternative terms are common for both 'social learning' (e.g. joint learning, collective learning, joint knowledge production) and 'resilience' (adaptive capacity, sustainability). This may affect the representativeness and generalizability of the reported findings, but a comprehensive review including alternative keywords was beyond the scope of this paper. However, as the reviewed set of studies mirrors the trend in the wider 'environmental learning' literature [45,46], viz. lack of methodological rigor and empirical evidence and an emphasis on local to regional scales, it is not expected that a larger collection would change the overall findings.
} 
Table 1

Learning outcomes and impacts on governance and management of social-ecological systems in 10 empirical studies on social learning; 'what' specifies the type and level of the system, 'who' specifies the participants in the social learning process.

\begin{tabular}{lllll}
\hline Source & \multicolumn{1}{c}{ What } & \multicolumn{1}{c}{ Who } & \multicolumn{1}{c}{ Outcomes } & Impacts \\
\hline 47 & $\begin{array}{l}\text { Forestry in western USA (local, } \\
5 \text { cases) }\end{array}$ & $\begin{array}{l}\text { Community-based forestry } \\
\text { organizations }\end{array}$ & $\begin{array}{l}\text { Shared understanding; } \\
\text { improved information base; trust }\end{array}$ & $\begin{array}{l}\text { Helped resolve conflicts; } \\
\text { changes in existing or adoption } \\
\text { of new practices }\end{array}$ \\
48 & $\begin{array}{l}\text { Paraiba do Sul river basin } \\
\text { management in Brazil (regional) }\end{array}$ & $\begin{array}{l}\text { River basin management } \\
\text { committee }\end{array}$ & $\begin{array}{l}\text { Shared understanding of } \\
\text { problems, possibilities, and } \\
\text { mission; trust; ability to work } \\
\text { together }\end{array}$ & $\begin{array}{l}\text { Successfully improved } \\
\text { (sustainable) water management } \\
\text { strategy during period of drought }\end{array}$ \\
43 & $\begin{array}{l}\text { Integrated management of } \\
\text { communal natural resources in }\end{array}$ & $\begin{array}{l}\text { Committees with } \\
\text { representatives from the rural contestation of }\end{array}$ & $\begin{array}{l}\text { Shifts in local rule making and } \\
\text { tranforcement }\end{array}$
\end{tabular}
South-Africa (local, 3 cases)

49 Dhuenn river basin management Informal participatory in Germany (regional) stakeholder platforms

Changes in frames and assumptions; consensus on possible measures; creation of networks

50 Co-management of narwhal, beluga and char fisheries in

Multi-actor platforms of arctic communities, hunters, Canadian Arctic (regional, scientists, managers

Trust; collective ownership of problem; ideas to improve management decisions; revised assumptions, worldviews 3 cases) 51 Management of wildfires in USA $\begin{aligned} & \text { Community members, } \\ & \text { flocal, } 4 \text { cases) }\end{aligned}$

\section{Implementation of river} management experiment; agenda for higher-level formal process; changes in financing of water management

No evidence of application of lessons in co-management

52 Agroforestry in Tanzania (local, large sample)

Agroforestry program participants (farmers, project staff, government officials, other stakeholders)

53 River management in UK; water resources management in South-Africa; climate adaptation of agriculture in Italy (national, 3 cases)

$54 \quad$ Integrated natural resources management in Mexico; coastal management in Argentina; forest management in Colombia (local, 3 cases)

55 Regional climate adaptation governance in Indonesia (regional, 5 cases)
Multi-level, multi-actor platforms of policy developers and policy implementers

Stakeholders from the local communities, plus external stakeholders (incl.

governmental)

Multi-stakeholder platforms with stakeholders from case study sub-districts Improved relationships, clarified responsibilities

\section{Strengthened local social} capital; consensus and convergence in decision making

Significant social learning

Shifts in understanding; new types of responses proposed
Improved communication systems, contributing to fire response efficiency and effectiveness

Potential conflicts avoided; more effective and socially robust solutions developed or adapted and integrated

Failure to move learning outcomes from platform to institutionalized governance processes

Shift towards transformative actions was 'less evident'

Trust; cross-scale networks; knowledge integration; innovative adaptation strategies
No or very limited evidence of institutional change to existing planning processes the learning and policy process $[48,49]$, whereas this was found lacking in the regional and national cases without impacts on governance and management $\left[50,53^{\bullet \bullet}, 55\right]$. According to the researchers this was because policy windows did not occur during the social learning process or were not used $\left[53^{\bullet \bullet}, 55\right]$. Policy windows are openings in governance regimes that are normally resistant to more fundamental change $\left[34^{\circ}\right]$. These windows are often associated with crises, when the need for change has become evident $\left[57^{\circ}, 58\right]$. To enhance the probability of occurrence and successful use of policy windows, the researchers propose to sustain the social learning process over a longer time period and to combine this with a more active, opportunity-seeking approach towards the formal policy process $\left[53^{\bullet \bullet}, 55\right]$. Possible ways to create more permanent settings for social learning are providing informal 'shadow spaces' within and between organizations [59] or establishing 'bridging organizations' as places of collaborative learning and management [60]. Before such more permanent settings are realized, individuals may play a key role in bridging learning and policy processes and exploiting policy windows. These so-called policy (or social) entrepreneurs perceive the need for change, build networks within and between levels of governance and mobilize other actors with their vision for an alternative approach $\left[57^{\circ}, 61\right]$.

In a recent study of adaptive governance, Schultz et al. $\left[15^{\circ}\right]$ found in the three successful cases an interplay between policy entrepreneurs, bridging organizations, and networks linking multiple levels of governance. This corresponds with the work of Pahl-Wostl et al. [34 $4^{\circ \bullet}$, who used a conceptual framework of the relations between informal, multi-loop learning and formal policy processes 
to analyze transformative change of governance regimes in flood management. In this framework, transformative change is possible when learning spaces and policy processes are linked through bridging organizations or individuals participating in both (policy entrepreneurs), and when there are strong linkages between governance levels to capture lessons learned at various levels. However, even then such change processes may take decades, and require at least two crises or extreme events. Pahl-

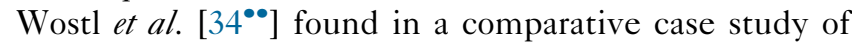
flood management that major transformations occurred after a disaster promoted the adoption of alternative strategies which were developed after earlier extreme events. This may be translated in terms of the adaptive cycle (Figure 2) as one crisis at the beginning of the back loop, to trigger double and triple-loop learning processes, and another crisis before entering the front loop, to institutionalize the learning outcomes.

\section{Conclusions and outlook}

The conceptualization of social learning and its relation with the resilience of social-ecological systems has advanced sufficiently to guide further empirical research. However, as these concepts are broad and their interpretation diverse, researchers must continue to be explicit about how the concepts are defined and operationalized. There is also a need to use more rigorous methods for measuring, monitoring and assessing social learning. Such methods are currently available $\left[26,30^{\circ}, 62-64\right]$, but still scarcely used. Given the limited niche for fostering of social learning through intentional, organized interventions, and the significant investments required to generate outcomes, further research could best focus on making these investments as effective as possible by optimization of intervention process design and support of the learning process. Issues of interest concern the opportunities provided by new technologies to support, for example, social learning for future climate change with model simulations [65], or wider social learning through internet communities around participatory monitoring $\left[2^{\circ}, 66\right]$. A novel and very different approach to study social learning in the context of resilience are controlled behavioral micro-level experiments $\left[67^{\circ}\right]$. This type of experiments is too artificial to provide evidence about the real-world relationship between social learning and resilience, but proved very effective in generating hypotheses to guide real-world research on, for example, better design of interventions aimed at social learning.

A review of empirical studies on the contribution of social learning to resilience of social-ecological systems, indicated that this relation has rarely been studied explicitly, but inferred from the impacts of social learning on governance and management of the system and thus on the adaptive capacity. At lower levels (e.g. local), positive impacts are found more frequently than at higher levels (e.g. national), due to an overlap between participants in social learning and actors in governance and management. At higher levels, a better connection between informal social learning processes and formal policy processes can be achieved through an interplay of bridging actors and/or organizations, and vertical linkages between governance levels. The scope for intentionally creating such adaptive governance systems seems limited, amongst others due to dependence on individuals with specific qualities (policy entrepreneurs) and the occurrence of crisis-linked policy windows. Nevertheless, other factors provide scope for design such as the creation of informal learning spaces in connection to the formal policy structure. Methods and analytical frameworks are currently available for longitudinal case study research $\left[15^{\circ}, 34^{\circ}\right]$, to identify how this can be achieved in different governance contexts. A question of particular interest is how such learning spaces can be opened up to a diversity of stakeholders, as current examples of informal learning networks within formal policy structures appear to be expert-dominated $\left[34^{\bullet \bullet}\right]$, which creates risks of legitimacy and public opposition in the policy implementation phase. The most urgent and difficult open question, however, concerns how largescale, future problems that require present action can be tackled with adaptive governance. Given the importance of crises in creating space for learning and windows for fundamental policy change, how can we organize social learning and adaptation ahead of the crisis?

\section{References and recommended reading}

Papers of particular interest, published within the period of review, have been highlighted as:

- of special interest

$\bullet$ of outstanding interest

1. Biggs $R$, Schlüter $M$, Biggs $D$, Bohensky EL, BurnSilver $S$, Cundill G, Dakos V, Daw TM, Evans LS, Kotschy K, Leitch AM, Meek C, Quinlan A, Raudsepp-Hearne C, Robards MD, Schoon ML, Schultz L, West PC: Toward principles for enhancing the resilience of ecosystem services. Annu Rev Environ Resour 2012, 37:421-448.

2. Cundill G, Leitch AM, Schultz L, Armitage D, Peterson G: Principle - 5 - encourage learning. Principles for Building Resilience: Sustaining Ecosystem Services in Social-Ecological Systems. United Kingdom: Cambridge University Press; 2015, 174-200. A recent and comprehensive review on learning as a mechanism to build resilience, used as the starting point for this paper. A drawback is that in many instances no clear distinction is made between different forms of learning, including social learning.

3. Biggs $R$, Schlüter $M$, Schoon ML: An introduction to the resilience approach and principles to sustain ecosystem services in social-ecological systems. Principles for Building Resilience: Sustaining Ecosystem Services in Social-Ecological Systems. United Kingdom: Cambridge University Press; 2015, 131.

4. Folke C, Hahn T, Olsson P, Norberg J: Adaptive governance of social-ecological systems. Annu Rev Environ Resour 2005, 30:441-473.

5. Armitage DR, Plummer R, Berkes F, Arthur RI, Charles AT, Davidson-Hunt IJ, Diduck AP, Doubleday NC, Johnson DS, Marschke M, McConney P, Pinkerton EW, Wollenberg EK: Adaptive co-management for social-ecological complexity. Front Ecol Environ 2009, 7:95-102.

6. Holling CS: Resilience and stability of ecological systems. Annu Rev Ecol Syst 1973, 4:1-23. 
7. Walker B, Gunderson L, Kinzig A, Folke C, Carpenter S, Schultz L: A handful of heuristics and some propositions for understanding resilience in social-ecological systems. Ecol Soc 2006, 11.

8. Hahn T, Nykvist B: Are adaptations self-organized, autonomous, and harmonious? Assessing the socialecological resilience literature. Ecol Soc 2017, 22.

9. Folke C: Resilience: the emergence of a perspective for socialecological systems analyses. Glob Environ Change 2006, 16:253-267.

10. Muro M, Jeffrey P: A critical review of the theory and application

- of social learning in participatory natural resource management processes. J Environ Plan Manag 2008, 51:325344.

A milestone in social learning research revealing the lack of conceptual clarity and empirical evidence thus far. Still worthwhile reading to understand the limitations of social learning as a governance mechanism.

11. Reed MS, Evely AC, Cundill G, Fazey I, Glass J, Laing A, Newig J, Parrish B, Prell C, Raymond C, Stringer LC: What is social learning? Ecol Soc 2010, 15:1-10.

12. Berkes F, Colding J, Folke C: Rediscovery of traditional ecological knowledge as adaptive management. Ecol Appl 2000, 10:1251-1262

13. Berkes F: Evolution of co-management: role of knowledge generation, bridging organizations and social learning. $J$ Environ Manag 2009, 90:1692-1702.

14. Pahl-Wostl C: A conceptual framework for analysing adaptive capacity and multi-level learning processes in resource governance regimes. Glob Environ Change 2009, 19:354-365.

15. Schultz L, Folke C, Österblom H, Olsson P: Adaptive governance,

- ecosystem management, and natural capital. Proc Natl Acad Sci USA 2015, 112:7369-7374.

This paper presents convincing evidence that learning-based, adaptive governance, performs better than conventional approaches in the management of natural capital, and elucidates the mechanisms by which this is achieved.

16. Holling CS: Report: royal commission on the economic union and development prospects for Canada. Environment 1986, 28:25-28

17. Berkes F, Folke C: A systems perspective on the interrelations between natural, human-made and cultural capital. Ecol Econ 1992, 5:1-8.

18. Gunderson L: Resilience, flexibility and adaptive management - antidotes for spurious certitude? Conserv Ecol 1999, 3.

19. Maarleveld M, Dabgbégnon C: Managing natural resources: a social learning perspective. Agric Hum Values 1999, 16:267-280.

20. Leeuwis C, Pyburn R (Eds): Wheelbarrows Full of Frogs: Social Learning in Rural Resource Management. The Netherlands: Van Gorcum; 2002.

21. Wals EJ (Ed): Social Learning Towards a Sustainable World. The Netherlands: Wageningen Academic Publishers; 2007.

22. Lee K: Appraising adaptive management. Conserv Ecol 1999, 3.

23. Keen M, Brown VA, Dyball R (Eds): Social Learning in Environmental Management: Towards a Sustainable Future. Routledge; 2005.

24. Tompkins $E$, Adger WN: Does adaptive management of natural resources enhance resilience to climate change? Ecol Soc 2004, 9.

25. Adger WN, Hughes TP, Folke C, Carpenter SR, Rockström J: Social-ecological resilience to coastal disasters. Science 2005, 309:1036-1039.

26. Van der Wal M, De Kraker J, Offermans A, Kroeze C, Kirschner PA, van Ittersum M: Measuring social learning in participatory approaches to natural resource management. Environ Policy Gov 2014, 24:1-15.
27. Scholz G, Dewulf A, Pahl-Wostl C: An analytical framework of social learning facilitated by participatory methods. Syst Pract Action Res 2014, 27:575-591.

28. Cundill G, Rodela R: A review of assertions about the processes and outcomes of social learning in natural resource management. J Environ Manag 2012, 113:7-14.

29. Loeber A, van Mierlo B, Grin J, Leeuwis C: The practical value of theory: conceptualising learning in the pursuit of a sustainable development. Social Learning Towards a Sustainable World. Wageningen, The Netherlands: Wageningen Academic Publishers; 2007, 83-98

30. Beers PJ, van Mierlo B, Hoes AC: Toward an integrative - perspective on social learning in system innovation initiatives. Ecol Soc 2016, 21.

This paper presents and applies an elaborate conceptual and analytical framework to study social learning, built on insights from natural resources management as well as educational science. Learning process, outcomes and impacts are clearly distinguished in this framework.

31. Holling CS: Understanding the complexity of economic, ecological, and social systems. Ecosystems 2001, 4:390-405.

32. Holling CS: From complex regions to complex worlds. Ecol Soc - 2004, 9:11.

A very accessible account of the development of his thinking from the godfather of resilience. Includes a clear explanation of the adaptive cycle, and its relation to learning and resilience.

33. Argyris C, Schön DA: Organisational Learning II: Theory, Method and Practice. Reading: Addison-Wesley; 1996.

34. Pahl-Wostl C, Becker G, Knieper C, Sendzimir J: How multilevel

-• societal learning processes facilitate transformative change: a comparative case study analysis on flood management. EcOl Soc 2013, 18:58.

This paper presents a relatively simple, yet comprehensive conceptual framework of how informal learning processes and formal policy processes may interact to effect transformative change of governance regimes. Application of the framework in three large-scale, long-term case studies demonstrate its usefulness to further research.

35. Jiggins $\mathrm{J}$, van Slobbe $\mathrm{E}$, Röling $\mathrm{N}$ : The organisation of social learning in response to perceptions of crisis in the water sector of The Netherlands. Environ Sci Policy 2007, 10:526-536.

36. Pahl-Wostl C, Hare M: Processes of social learning in integrated resources management. J Commun Appl Soc Psychol 2004, 14:193-206.

37. Pahl-Wostl C, Craps M, Dewulf A, Mostert E, Tabara D, Taillieu T: Social learning and water resources management. Ecol Soc 2007, 12.

38. Röling N: Beyond the aggregation of individual preferences: moving from multiple to distributed cognition in resource dilemmas. Wheelbarrows Full of Frogs: Social Learning in Rural Resource Management. The Netherlands: Van Gorcum; 2002, 25-48.

39. Leeuwis C: Making explicit the social dimensions of cognition Wheelbarrows Full of Frogs: Social Learning in Rural Resource Management. 2002:391-406.

40. Aarts N, van Woerkum C: Dealing with uncertainty in solving complex problems. Wheelbarrows Full of Frogs: Social Learning in Rural Resource Management. 2002:421-437.

41. Mostert E, Pahl-Wostl C, Rees Y, Searle B, Tàbara D, Tippett J: Social learning in European river-basin management: barriers and fostering mechanisms from 10 river basins. Ecol Soc 2007, 12.

42. Van Bommel S, Röling N, Aarts N, Turnhout E: Social learning for solving complex problems: a promising solution or wishful thinking? A case study of multi-actor negotiation for the integrated management and sustainable use of the Drentsche Aa area in the Netherlands. Environ Policy Gov 2009, 19:400-412.

43. Cundill G: Monitoring social learning processes in adaptive comanagement: three case studies from South Africa. Ecol Soc 2010, 15:28. 
44. Schusler TM, Decker DJ, Pfeffer MJ: Social learning for collaborative natural resource management. Soc Nat Resour 2003, 16:309-326

45. Siebenhüner B, Rodela R, Ecker F: Social learning research in ecological economics: a survey. Environ Sci Policy 2016, 55:116-126.

46. Gerlak AK, Heikkila T, Smolinski SL, Huitema D, Armitage D:

- Learning our way out of environmental policy problems: a review of the scholarship. Policy Sci 2017:1-37.

A systematic and comprehensive review of learning research in the context of environmental governance, revealing methodological weaknesses, lack of empirical evidence and a focus on local to regional scales.

47. Fernandez-Gimenez M, Ballard H, Sturtevant V: Adaptive management and social learning in collaborative and community-based monitoring: a study of five communitybased forestry organizations in the western USA. Ecol Soc 2008, 13.

48. Kumler L, Lemos M: Managing waters of the Paraíba do Su river basin, Brazil: a case study in institutional change and social learning. Ecol Soc 2008, 13.

49. Moellenkamp S, Lamers MAJ, Huesmann C, Rotter S, Pahl-Wostl C, Speil K, Pohl W: Informal participatory platforms for adaptive management. Insights into niche-finding, collaborative design and outcomes from a participatory process in the Rhine basin. Ecol Soc 2010, 15:41.

50. Armitage D, Berkes F, Dale A, Kocho-Schellenberg E, Patton E: Co-management and the co-production of knowledge: learning to adapt in Canada's Arctic. Glob Environ Change 2011, 21:995-1004.

51. Jakes PJ, Sturtevant V: Trial by fire: community wildfire protection plans put to the test. Int J Wildland Fire 2013, 22:1134-1143.

52. Johansson KE, Axelsson R, Kimanzu N: Mapping the relationship of inter-village variation in agroforestry tree survival with social and ecological characteristics: the case of the Vi agroforestry project, Mara Region, Tanzania. Sustainability 2013, 5:5171-5194.

53. Colvin J, Blackmore C, Chimbuya S, Collins K, Dent M, Goss J,

-. Ison R, Roggero PP, Seddaiu G: In search of systemic innovation for sustainable development: a design praxis emerging from a decade of social learning inquiry. Res Policy 2014, 43:760-771.

A rare example of a follow-up study to investigate the impacts on governance and management of organized social learning processes after 10 years. It demonstrates clearly that high-level impacts require a long-term investment in social learning and an active approach towards the formal policy process

54. Brown I, Martin-Ortega J, Waylen K, Blackstock K: Participatory scenario planning for developing innovation in community adaptation responses: three contrasting examples from Latin America. Reg Environ Change 2016, 16:1685-1700.

55. Butler JRA, Suadnya W, Yanuartati Y, Meharg S, Wise RM, Sutaryono Y, Duggan K: Priming adaptation pathways through adaptive co-management: design and evaluation for developing countries. Clim Risk Manag 2016, 12:1-16.

56. Von Hippel E: "Sticky information" and the locus of problem solving: implications for innovation. Manag Sci 1994, 40:429-439.

57. Biggs R, Westley F, Carpenter S: Navigating the back loop:

- fostering social innovation and transformation in ecosystem management. Ecol Soc 2010, 15.

Detailed analysis of three cases of transformative change in local ecosystem management. Key factors include reframing of perspectives, which can be understood as an outcome of social learning, and policy (or social) entrepreneurship.

58. Nykvist B: Does social learning lead to better natural resource management? A case study of the modern farming community of practice in Sweden. Soc Nat Resour 2014, 27:436-450.

59. Pelling M, High C, Dearing J, Smith D: Shadow spaces for social learning: a relational understanding of adaptive capacity to climate change within organisations. Environ Plan A 2008, 40:867-884

60. Crona B, Parker J: Learning in support of governance: theories, methods, and a framework to assess how bridging organizations contribute to adaptive resource governance. Ecol Soc 2012, 17.

61. Olsson P, Gunderson L, Carpenter S, Ryan P, Lebel L, Folke C, Holling CS: Shooting the rapids: navigating transitions to adaptive governance of social-ecological systems. Ecol Soc 2006, 11.

62. Haug C, Huitema D, Wenzler I: Learning through games? Evaluating the learning effect of a policy exercise on European climate policy. Technol Forecast Soc Change 2011, 78:968-981.

63. Baird J, Plummer R, Haug C, Huitema D: Learning effects of interactive decision-making processes for climate change adaptation. Glob Environ Change 2014, 27:51-63.

64. Scholz G, Austermann M, Kaldrack K, Pahl-Wostl C: Evaluating group model building exercises: a method for comparing externalized mental models and group models. Syst Dyn Rev 2015, 31:28-45

65. De Kraker J, Kroeze C, Kirschner P: Computer models as social learning tools in participatory integrated assessment. Int $J$ Agric Sustain 2011, 9:297-309.

66. Oldenhuizing J, de Kraker J, Valkering P: Design of a quality-oflife monitor to promote learning in a multi-actor network for sustainable urban development. J Clean Prod 2013, 49:74-84.

67. Yu DJ, Shin HC, Pérez I, Anderies JM, Janssen MA: Learning for - resilience-based management: generating hypotheses from a behavioral study. Glob Environ Change 2016, 37:69-78.

A novel, laboratory-based, experimental approach to study the relation between learning and resilience. The results confirm the importance of multiple-loop learning to effectively adapt resource management to unpredictable environmental change, and generate interesting hypotheses concerning the social conditions under which multiple-loop learning may occur. 